\title{
Independent Directors, Board Leadership Structure and Corporate Financial Performance: Evidence from Jordan
}

\author{
Dea'a Al-Deen Omar Al-Sraheen \\ Department of Accounting, Faculty of Economics and Administrative Sciences. Al al-Bayt University. Mafraq, Jordan, \\ E-mail:Dr-deaa@aabu.edu.jo
}

\begin{abstract}
This study seeks to further light on the financial performance of Jordanian industrial companies, especially from 2015 to 2019. The study aims to examine the impact of the independence of the board of directors and the leadership structure represented by the (CEO duality) on corporate financial performance. The study reported that there is a positive and significant relationship between the independence of the board of directors and the financial performance of companies, and a significant negative relationship between the duality of the CEO and financial performance. This study contributes to previous literature by beginning to address knowledge gaps about the role of the company's board and leadership structure on the performance of companies in emerging markets, especially in light of mixed and inconclusive results. These results indicate that the separation of the position of CEO and president is necessary to improve the financial performance of companies and this view was considered as the main recommendation of this study.

Key words

Financial Performance, Board Independence, Leadership Structure, CEO Duality, Jordan

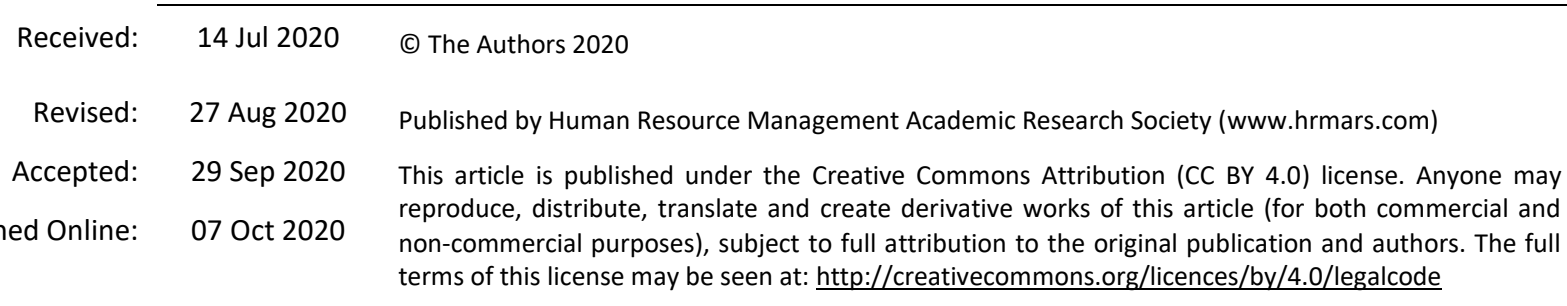

\section{Introduction}

Corporate boards play a vital and significant role in monitoring and controlling corporate management and aligning the shareholders' and management interests, it's also deemed as the key and dominant internal governance mechanism (Brennan, 2006). Boards may offer strategic guidelines for the management and may even act to revise and ratify proposals that offered by corporate management as mentioned by Jonsson (2005). In addition, boards of firms can also practice the function of a whistleblower through spotting problems early (Salmon, 1993). Thus, the responsibility of corporate boards is mainly for diligence and care, along with ensuring the effectiveness of financial controls.

However, the main debate in the previous literature on the ability of corporate boards to monitor corporate management, as mentioned by Braun and Sharma (2007), has attracted attention and has been the main motivation for carrying out such research, where the influential in arising such problem was the waves of the collapse of mega-companies such as WorldCom, Enron and HIH Insurance, in addition to BCCI and Maxwell Publishing Group, which erupted in the early 2000s (Mizruchi, 2004). Despite the proliferation of research in this regard, there is still much argument in the boards of directors and the corporate performance association.

The Jordanian corporate governance code included responsibilities and duties of the corporate board of directors to enhance corporate performance for example ensuring the integrity and adequacy of the 
internal control systems and reviewing and adopting a strategic plan of corporate (SDC, 2020). In general, the current research seeks to examine whether the independent board and the leadership structure influence corporate performance for listed firms in Jordan. The contribution of the current study to the previous literature and build knowledge on the role of the corporate boards in the emerging market context.

\section{Literature Review and Hypotheses Development}

The independence of the board considered as the essence of many reforms that conducted to the codes of corporate governance, both in emerging and developed countries, decrease the potential for the complicity of senior executives and avoid the misuse of company resources, and consequently, they improve performance (Black et al., 2006; Al-Sraheen \& Al Daoud, 2018).

Agency theorists have argued that the key task of the corporate board is to control and monitor the behavior of the corporate managers "agents" in order to maintain the interest of corporate owners "principals" (Hillman \& Dalziel, 2003; Al-Sraheen \& Alkhatib, 2016). The rationale for favoring independent (external) directors is that external members can make a positive contribution to the monitoring tasks and responsibilities of corporate boards (Park \& Shin, 2004) and thus add a great value to the company. The independent board maintains the balance of power between outsiders and insiders as documented by agency theory. Boards without independent directors will be dominated by insiders and can gain massive power that it may abuse. Furthermore, without the expertise of outside directors, boards can be ineffective (Dalton \& Daily, 1999).

The relationship between the independent board of directors and corporate financial performance is mixed and the findings are still inconclusive. Several empirical studies such as Coles, Danielb, and Naveen (2012); Olusola \& Abiodun (2013) who have documented a positive association between board independence and firm's performance. They pointed out that the independent members are free of bias due to their financial independence of management, they also have the ability to protect the shareholders' rights, provide the best form of monitoring to manage the corporate resources, and mitigation of agency problems as well. In addition, Daily et al. (2003) have pointed out that the existence of many outside directors may save the corporate from the risk of bankruptcy. Thus, it can be said that the existence of outside directors may leads to better financial performance. Thus, the current study expects the following research hypothesis:

\section{H1: independent board and corporate performance are positively related with one another.}

Regarding the leadership structure, the leading role of the CEO in achieving the success of the firm has a controversial effect on the stages of growth of the company. The change in CEO duality was expected to be more explicit in the maturity stage, the decline stage, and then affecting corporate performance. Peng et al. (2007) justified their assumption that start-ups are often managed and owned by family members (founders). Therefore, the positive impact of CEO duality on corporate performance will be clear because the company must have proper direction and focus, especially at this stage. Such a view is consistent with the theory of stewardship (Donaldson \& Davis, 1991) which documented that the duality of the CEO will aid and support decision-making, particularly in urgent circumstances.

However, companies will have more serious representation problems and will depend less on external resources in the maturity and decline stage than in the growth stage. Therefore, the company will decrease the need for resources and improve management supervision to reduce representation problems between managers and shareholders, so that the duality of the CEO undermines the supervisory role of the corporate board and negatively influences the performance of firms. This perspective is quite close to the representative theory view (Jensen \& Meckling, 1976) that CEO duality plays a negative role in corporate financial performance.

The purpose of separation is to maintain scales of power among the two designations in addition to avoid escalating conflicts of interest. In the absence of separation, the CEO who control the board is likely to lead to poor performance and more agency problems (Al Daoud et al., 2018). Consequently, the duality of duties attracts more conflicts and reduces corporate performance, and thus, from these points of view, the current study proposes the following research hypotheses: 
H2: Firm performance is negatively influenced by CEO duality.

\section{Methodology of research}

\subsection{Unit of Analysis}

The unit analysis is secondary data that represent the annual reports of industrial firms listed on the Amman Stock Exchange (ASE). The study period extends from 2015 to 2019. Based on the availability of corporate annual reports, this study considers 48 and 240 observations from the industrial firms listed on the ASE from 2015 to 2019 , which represents $85.7 \%$ of the total firms in this sector as of 31 Dec. 2019. The final sample consists of 240 observations.

\subsection{Econometric Model and Operationalization of Variables}

In the current study, the following regression model is used to test the research hypotheses.

$$
F P_{i t}=\beta_{0}+\beta_{1} B I_{i t}+\beta_{2} C E O_{i t}+\varepsilon_{i t}
$$

Where:

$\mathrm{FP}=$ Firm performance measured by return on assets, net income divided by total assets

$\mathrm{BI}=$ "Board Independence, proportion of outside to total directors"”

CEO = "CEO Duality, score of (1) is given if the post is hold by same person as the CEO and board Chair, or is (0) otherwise".

$\varepsilon=$ is an error

\subsection{Analysis and Results}

This section illustrates the data analysis including; descriptive statistics and the hypotheses test using multiple regression.

Table 1 below shows the descriptive statistics of the research variables. The average value of ROA arrived at $(1.61 \%)$ for the overall sample with a maximum value $(82 \%)$ and the minimum is close to $(-66)$. These results are quite similar to the results of Makhlouf's study (2018). The CEO duality shows that the CEO of $70 \%$ of Jordanian firms serves as chairman.

Table 1. Descriptive Statistics

\begin{tabular}{l|c|c|c|c} 
& Minimum & Maximum & Mean & Std. Deviation \\
\hline $\mathrm{BI}$ & .07 & .84 & .5750 & .25688 \\
\hline $\mathrm{CEO}$ & .00 & 1.00 & .7059 & .46018 \\
\hline $\mathrm{ROA}$ & -66.00 & 82.00 & 1.6078 & 41.84499 \\
\hline
\end{tabular}

\subsection{Multivariate Analysis}

The main assumptions of the regression were tested before starting to test the research hypotheses in order to ensure the integrity and validity of the data for analysis. The variance inflation factors (VIFs) are employed in this study to detect the multicollinearity existence. Based on the values of the VIF which are less than 10, thus, the multicollinearity is not a problem in the research model. Secondly, the DurbinWatson value was used to investigate if the variables in the research model are serially correlated in all conditions. The value of the Durbin-Watson was 2.01 which reveals that the research models do not suffer from the autocorrelation.

Table 2. Regression Results

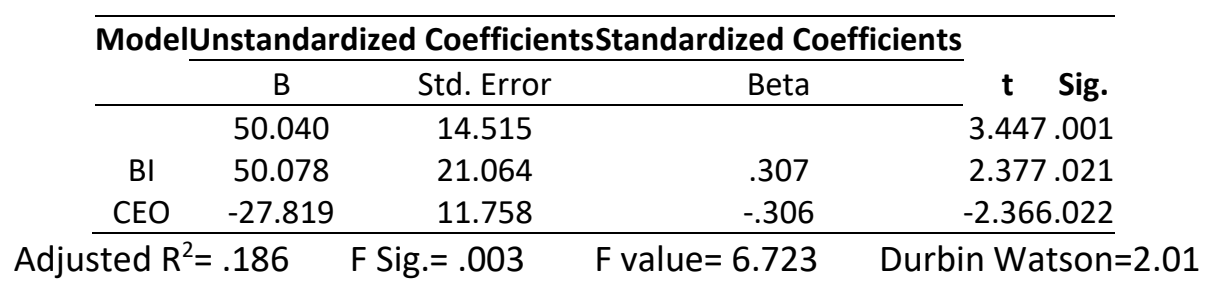


The results showed that the research model is a strong and statistically significant, based on the values of $(F=6.723$; Sig.= .003). In addition, the research model contributes to explaining $18.6 \%$ of the variation in the dependent variable (corporate performance) through the adjusted $R^{2}$ value.

Regarding the first research hypothesis, which stated that the independence of the board was positively correlated with the performance of the company? The result shows that the independence of the board of directors has a significant positive association with corporate performance based on the values of $(\mathrm{t}=2.377$; Sig. $=.021)$ and consequently consistent with our hypotheses. The finding is consistent with Saat et al. (2011) and Johari et al. (2008) who documented a positive influence on corporate performance because more outside (independent) directors on board will solve the agency problems, and it could be able to employ outside expertise that will yield corporate performance.

Our result supports the agency theory view that CEO duality will offer a powerful CEO with entire power and can harm the supervision role of the board (Adams et al., 2005). Also, the results of this study show that the outside directors are unable to achieve results to the company due to their disrupted role and responsibilities to supervising and consulting the behavior of corporate managers. Thus, the agency theory and the stewardship theory advocate for the two roles separation and posit that corporate managers have self-seeking motives and, in most cases, they utilize the chance to act contrary to the holders of capitals' interests (Korir \& Tenai, 2020).

\section{Conclusions and Recommendations}

This study depends mainly on examining the influence of the board's independence and the CEO duality on the corporate performance of the Jordanian companies listed on the ASE. The study documented a set of results that were discussed previously and centered on the existence of a positive and significant relationship between the independence of the board of directors and the performance of companies, in addition, there is a negative and significant relationship between the CEO duality and the corporate performance. This study recommends and based on what has been observed from the results, the necessity to clarify the danger of duality of CEO/Chairman on the company's performance, especially since the results showed that $70 \%$ of Jordanian companies have such duality

\section{References}

1. Adams, R. B., Almeida, H., \& Ferreira, D. (2005). Powerful CEOs and their impact on corporate performance. The Review of Financial Studies, 18(4), 1403-1432.

2. Adebayo, O. S., Olusola, A. G., \& Abiodun, O. F. (2013). Relationship between corporate governance and organizational performance: Nigerian listed organizations experience. International Journal of Business and Management Invention, 2(9), 1-6.

3. Al Daoud, K. A., Al-Sraheen, D. A. A. D., \& Aleqab, M. M. (2018). Does CEO Duality and Family Ownership Concentration Hinder the Effectiveness of the Corporate Board of Directors in Jordanian Service Firms?. JOURNAL OF ENVIRONMENTAL ACCOUNTING AND MANAGEMENT, 6(2), 95-104.

4. Al Daoud, K. A., Jordan, A. J., \& Alslehat, N. A. A. (2015). The moderating effect of an audit committee on the relationship between non-audit services and corporate performance. Research Journal of Finance and Accounting, 6(14), 170-179.

5. Al-Sraheen, D. A. D., \& Alkhatib, K. (2016). Proposing a model for limiting earning management practices: The case of Jordanian listed firms. Corporate Board: role, duties and composition, 12(3), 81-84. DOI:10.22495/cbv12i3art9

6. Al-sraheen, O., Fadzil, F. H., Soffian, S., \& Ismail, B. S. (2014). Does corporate governance matter? Evidence from accounting conservatism practices among Jordanian listed companies.

7. Black, B. S., Jang, H., \& Kim, W. (2006). Does corporate governance predict firms' market values? Evidence from Korea. The Journal of Law, Economics, and Organization, 22(2), 366-413.

8. Braun, M., \& Sharma, A. (2007). Should the CEO also be chair of the board? An empirical examination of family-controlled public firms. Family Business Review, 20(2), 111-126.

9. Brennan, N. (2006). Boards of directors and firm performance: is there an expectations gap? Corporate Governance: An International Review, 14(6), 577-593. 
10. Coles, J. L., Danielb, N. D., \& Naveen, L. (2012). Boards: Does one size fit all? Journal of Financial Economics, 87(2), 329-356.

11. Daily, C. M., Dalton, D. R., \& Cannella Jr, A. A. (2003). Corporate governance: Decades of dialogue and data. Academy of management review, 28(3), 371-382.

12. Dalton, D. R., \& Daily, C. M. (1999). What's wrong with having friends on the board? Across the board, 36, 28-32.

13. Donaldson, L., \& Davis, J. H. (1991). Stewardship theory or agency theory: CEO governance and shareholder returns. Australian Journal of management, 16(1), 49-64.

14. Hillman, A. J., \& Dalziel, T. (2003). Boards of directors and firm performance: Integrating agency and resource dependence perspectives. Academy of Management review, 28(3), 383-396.

15. Jensen, M. C., \& Meckling, W. H. (1976). Theory of the firm: Managerial behavior, agency costs and ownership structure. Journal of financial economics, 3(4), 305-360.

16. Johari, N. H., Saleh, N. M., Jaffar, R., \& Hassan, M. S. (2009). The influence of board independence, competency and ownership on earnings management in Malaysia. International Journal of Economics and Management, 2 (2), 281-306.

17. Jonsson, E. I. (2005). The role model of the board: A preliminary study of the roles of Icelandic boards. Corporate Governance: An International Review, 13(5), 710-717.

18. Korir, F. J., \& Tenai, J. K. (2020). The Nexus between CEO Duality and Company Performance: Evidence from Listed Companies in Kenya. African Journal of Education, Science and Technology, 5(4), 8291.

19. Makhlouf, M. H., Laili, N. H., Ramli, N. A., Al-Sufy, F., \& Basah, M. Y. (2018). Board of directors, firm performance and the moderating role of family control in Jordan. Academy of Accounting and Financial Studies Journal, 22(5), 1-15.

20. Mizruchi, M. S. (2004). Berle and Means revisited: The governance and power of large US corporations. Theory and society, 33(5), 579-617.

21. Park, Y. W., \& Shin, H. H. (2004). Board composition and earnings management in Canada. Journal of corporate Finance, 10(3), 431-457.

22. Peng, M. W., Zhang, S., \& Li, X. (2007). CEO duality and firm performance during China's institutional transitions. Management and Organization Review, 3(2), 205-225.

23. Saat, N. A. M., Karbhari, Y., Heravi, S., \& Nassir, A. M. (2011). Effective oversight roles of board of directors-The case of listed firms on Bursa Malaysia. World review of business research, 1(1), 231-245.

24. Salmon, W. J. (1993). Crisis prevention: how to gear up your board. Harvard Business Review, 71(1), 68-75.

25. Securities Depository Center. (2020). Corporate Governance Code for Shareholding Companies Listed on the Amman Stock Exchange. available at: https://www.sdc.com.jo/english/images/stories/ pdf/corporateguidee.pdf

26. Al-Sraheen, A-D. D., \& Al Daoud, A. K. (2018). Does the presence of independent directors reduce the practices of earnings management? The moderating role of family ownership concentration. Ekonomski pregled, 69(6), 638-654. 